\title{
平均すべり面強度定数の算定方法について \\ Methods for Estimating the Parameters of Average Shear Strength alnog the Slip Surface
}

\author{
宜保清一* 武居有恒** 小波蔵政良*** \\ Seiichi Gibo Aritsune TakeI Seiryo Kohagura
}

\begin{abstract}
The strength parameters obtained from shear tests are only treated as reference data in the stability analysis of the landslide. In order to increase accuracy of the analysis, these parameters are directly or indirectly necessary for the estimation of design strength parameters.

In the present report, paying special attention to the slickenside and fully softened clay seams in the slip surface and joint surface, the authors pointed out the significance of the relation between the shear stress mobilized along the slip surface and three strengths, namely the residual, peak and fully softened strengths. They also proposed methods to determine the parameters of average shear strength, where the residual strength and other strengths, Mohr-Coulomb equation, and the residual factor $R$ were all introduced into the $c^{\prime}-\phi^{\prime}$ relationship that was obtained by the back analysis. Last of all, rationality of the abovementioned methods was also confirmed by applying the methods into examples of actual landslides.
\end{abstract}

\section{1. まえがき}

安定解析の精度を高める上で，すべり面の位置と土質 常数, 中でも剪断強度定数を明確に把握することは最も 重要であり, 地すべり・崩壊の調查・解析拉よび対策に 従事する者にとって苦虑するるのの一つである。笑際, 地すべり解析に怙いて安定計算にピーク強さを適用した のでは活動中であるにもかかわらず安全率が 1 よりも過 大になり，矛盾する。したがって，平均すべり面強さ $\bar{\tau}$ の定数 (粘着力 $\bar{c}^{\prime}$, 剪断抵抗角 $\phi^{\prime}$ ) を求めるのに, 通常 $F_{s}=1$ として $c^{\prime}-\phi^{\prime}$ 図を描き, 経験的に一方を仮定して 他方を決めている。しかし，それは裏付けを欠いている ため, 真の強度定数とは言い難く, 対策工法そのものが 不明確になっていることは従来から指摘されていると括 りである。

このようなすべり面強度定数の不鮮明さは, 主として すべり面やすべり領域の把握が困難であること和よび厳 密な意味での剪断試験法（試料の取扱いも含めて）や結 果の解积において曖昧さや未解明部分が多いことに因る ものである。

筆者等は, これまでに沖縄, 島尻層泥岩地帯の地すべ り・崩壊事例执よび剪断特性に関する実験的研究からこ
の種の問題に対していくつかの知見を得ている。また新 潟拉よび長野県等有数の地すべり多発地带の事例にも直 接触れ, 調查および研究成果について検討した。すべり 面強さの問題は, 底が樑くて不透明なものが複雑にから み合っているため，不明な点が多いが，これまでの実験 特よび調查研究から残留強さとすべり面強さの関係拈よ び設計定数の算定方法に関して 2,3 の成果が得られたの で報告する。

\section{2. すべり面形成と地質構造特性}

\section{（1）弱面やすべり面の状態}

安定解析に適用できる実験定数とするためには適正な 剪断試験方法を採用すべきであることはいらまでもない が，そのためにはすべり面あるいはすべり面領域の状 態, 地すべり・崩壊と土・岩質拉よび地質・構造との関 係を知ることが肝要である。これらに関して，代表的な 地すべり地域に执いてこれまでに確認されている特徽的 なことを挙げると，以下のようである。

島尻層泥岩は, 半固結の泥質堆積岩で, 過圧密土特有 の強度特性と物理・化学的特性を有する。層内には大小 の多くの断層が存在するばかりでなく、褶曲構造も認め られ，複雑な地殼変動を受けている。岩盤性の地すべり 性崩壊例では標準貫入試験等のサウンディングでは把握 しえないテクトニックな不連続面が潜在すべり面と なっていてすべり発生の素因となっている。断層面には 
Slickensideが形成されていて，条線の存在するものもあ り，その打向は断腐面の倾斜方向とほぼ一致している。 またキャップロックを背後に有し，居面の走们が斜面の 㑔斜广们と一致している場合は浸透水による風化によっ てかなりの深度まで軟化して強度を低下しているが，や はり腐面等がすべり面となっている。深度が $2 \sim 3 \mathrm{~m}$ 程度 の浅層すべり本例では表層土と風化泥岩の境界に高含水 の完全軟化粘土莎愿が挾在している1)。

中頸城および東頸城地域が新潟県下最大の地すべり地 となっている原因は, 椎谷扣よび寺泊層泥岩が優勢に発

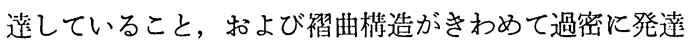
していることである。斜面深部の泥岩および凝灰岩は破 砕されていて脆弱化し, Slickensideや粘土薄層が確認さ れている2)。

長野囬北部はフォッサマグナ地域で，火成若を介在す る地区と断層破砕を受けている地区には複雑なすべり機 槛を持つ地すべりが多い3。すべり面付近では泥岩の脆 弱化および泥岩中に摤在している凝灰岩や凝灰質火砕岩 層の変質風化・モンモリロナイト化によって, 強度が低 下している。

龟の瀬地すべりのすべり屇準である龟の濑礫層は層厚 1〜2mで, 含花ュウ岩䃯の凝灰質砂岩を主体とし, 他に 凝灰質粘土を含んでいる。全体的に粘土化が進行し, Slickensideが数多く発達している。現存する構造は, 地 すべり運動によるものと思われ，全て，主すべり面と一 致していることから，剪断方向はほぼ構造に支配される とみなしている。どの観察深度に特いても龟の瀬喽層の 中・下部付近に一枚の平滑な連続性のよい分離面が存在 していて主すべり面となっている4)。

これらに其通していることは，従来から指摘されてい
る泥岩や凝灰岩特有の強度低下に加兄て, 地質 - 構造的 な不連績面や既存のすべり面に技ける Slickenside の存 在に注目し，それを地すべり発生や二次すべりの素因と していることである。

\section{（2）すべり面形成後のすべり面強さ}

すべり移動後の斜面は見かけ上安定化地形になったと みなされるが，層中にすべり面が形成されているばかり でなく，ところによっては Slickenside が形成されてい て強度を低下させているために，道路復旧等のための末 端部切取工が二次すべりをまねいたり, 地下水位上昇に よって斜面が不安定になりやすくなっている。

すべりに抵抗するすべり面強さは，すべり発生時に最 大值を示し, その後, 移動の增大と共に漸減し, 最終的 には残留強さに近い值まで低下する。すべりが休止して いる場合はすべり領域に存在する高含水の軟弱粘土にチ キソトロピーによる強度回復があるため, 完全軟化強さ の部分的寄与が期待できる。したがって，現在の状態を 活動中とみるか, 静止しているとみるか, あるいは断続 的なものとみるかによって, 強度定数および安全率がわ ずかながら異なることになる。

\section{3. 残留強さ}

\section{（1）剪断面の状態と残留強さの変化}

図-1 に泥岩の作成分離面についての代表的な剪断応 力・垂直変位〜変位関係を示す。実験は, 沖縄, 豊見城 地内地すべり性崩壊の採取泥岩について供試体の上・下 分離面を粗または滑面仕上げとして水浸括よび非水浸の リング剪断試験を行ったものである。これらの関係は分 離面の粗および滑の影絃を全体的に把握するために簢潔 に描かれているが，実際には変位に伴って応力がかなり
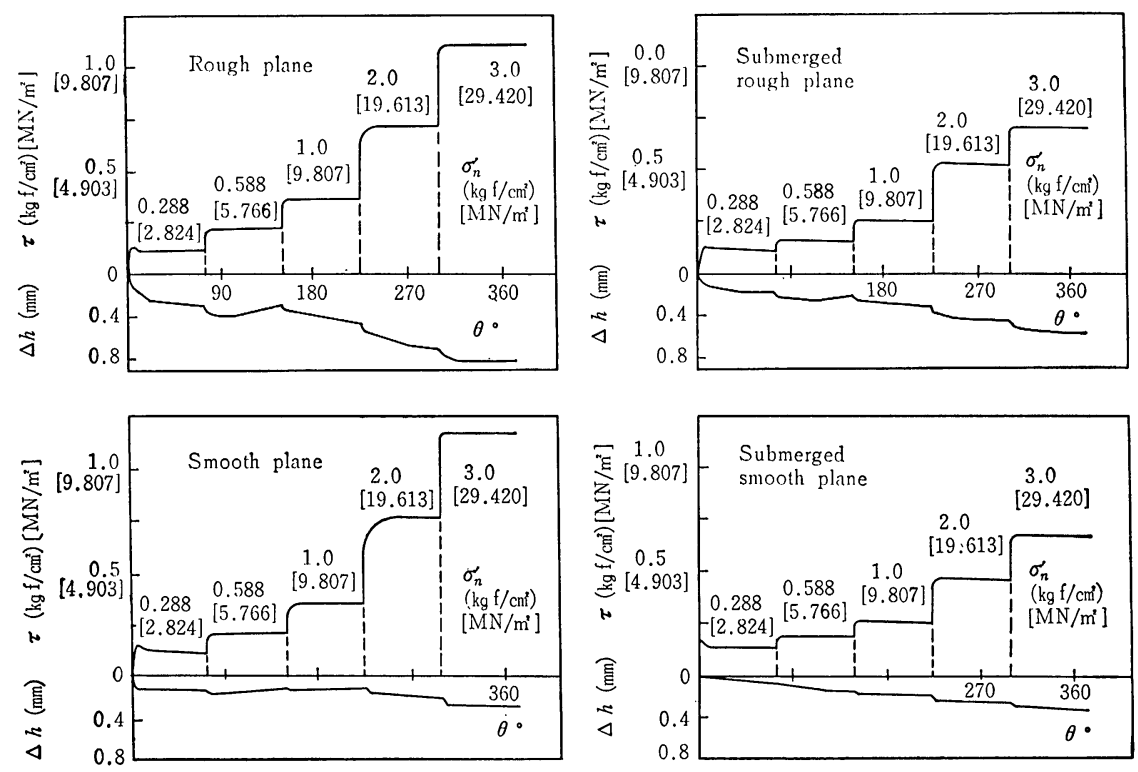

図-1 島尻徉泥岩分離面の剪断挙動におよぼす粗・滑面および介在の影響 (リング剪断試験結果) ${ }^{1)}$ 
複雑に変動している。剪断応力に対しては水浸か非水浸 かの剪断条件の違いが，垂直変位に対しては剪断時に生 成される破砕土粒子の多少が直接反映される。

そして, 残留剪断抵抗角は剪断面の発達如何によって 大きく変化していて, $\phi_{d r}=10^{\circ}$ 之 $20^{\circ}$ 程度の二つのグル ープに大別できる。前者は, 剪断面に Slickenside が形 成され, 介在物質である破砕土粒子と水が強度低下の重 要因子となって下限の残留值を与兄る。それに対して, 後者は, 剪断面に水の存在が認められない場合, 軟化泥 岩の水漫試験の上うに高含水の粘土薄層が形成されるこ とによって正規的な剪断特性を示す場合である。

したがって， Slickensideを呈する既存のすべり面や構 造的な不連続面が内在する泥岩斜面では，少量の粘土粒 子と水が相互に滑剤的な役割を担って強度を著しく低下 させる現象が重要となる。そして，実際のすべり面にお いては応力集中に伴って押し出される水5) の存在が確認 されているので, 粘土質島屑層泥岩のすべり面では $\phi_{d r}$ $=10^{\circ}$ 程度の残留剪断抵抗角が動員されているものと解 釈できる1。
（2）代表的な地すべり・崩壊土·岩の残留剪断抵抗角 表-1 亿代表的な地すべり試料の残留剪断抵抗角 $\left(\phi_{r}\right)$ 之塑性指数 $(P I)$, 粘土分 $(C F)$ 特よび活性度 $\left(A_{c}\right)$ を 示す。帛尻層泥岩は具志頭と崎山試料を除きすべり面付 近の採取土・岩塊である。その主要粘土鉱物であるスメ クタイトは28〜 35\%の簌囲に納まっていて，物理的珄質 も具志頭を除き類似している。凝灰質砂岩は強風化岩 で，砂和よびシルト粒子が多い割に高塑性であり，スメ クタイトの影響が顕著にあらわれている6)。各試料の残 留剪断抵抗盾 $\phi_{r}$ は $c_{r}=0$ として求めてあるので, $c_{r} \neq 0$ の場合は $1 \sim 2^{\circ}$ 高めの值となっている。例光ば, 検証 のために使用されたベントナイトの定数は政密には $c_{r}=$ $0.04 \mathrm{kgf} / \mathrm{cm}^{2}, \phi_{r}=5.4^{\circ}$ であるが， $c_{r}=0$ とおいて $\phi_{r}=$ $6.8^{\circ}$ としている。この值は, ベントナイトがスメクタイ トとほとんど同一視されていることから，如何なる自然 土・岩が示す残留剪断抵抗角よりも一段と小さいもので ある。表には，他に Bishop 等の行った London clayに ついての実験結果7),8) も併記し，比較に供した。

表-1. 地すべり土の残留剪断抵抗角と塑性指数，粘土分および活性度

\begin{tabular}{|c|c|c|c|c|c|c|c|c|c|}
\hline \multirow[t]{2}{*}{ Samples } & \multirow[t]{2}{*}{$L L(\%)$} & \multirow[t]{2}{*}{$P L(\%)$} & \multirow[t]{2}{*}{$P I$} & \multirow{2}{*}{$\begin{array}{l}C F(\%) \\
(<2 \mu \mathrm{m})\end{array}$} & \multirow[t]{2}{*}{$A_{c}$} & \multicolumn{3}{|c|}{$\phi_{r}\left(^{\circ}\right)$} & \multirow[t]{2}{*}{ Remarks } \\
\hline & & & & & & (a) & (b) & (c) & \\
\hline \multicolumn{10}{|l|}{ Shimajiri Mudstone } \\
\hline (1) Maaji(1) & 72 & 24 & 48 & 51 & 0.94 & 10.7 & & $22.7(1)^{\prime \prime}$ & \\
\hline (2) Maaji(2) & 60 & 23 & 37 & 43 & 0.86 & 15.1 & & $21.4(2) "$ & \\
\hline (3) Gushichan & 50 & 25 & 25 & 20 & 1.25 & 28.8 & & $30.4(3)^{\prime \prime}$ & \\
\hline (4) Tomigusuku & 63 & 29 & 34 & 50 & 0.68 & 13.7 & 19(4)' & & \\
\hline (5) Onaga & 69 & 30 & 39 & 30 & 1.30 & 12.2 & & & \\
\hline (6) Sakiyama & 58 & 23 & 35 & 29 & 1.20 & 19.7 & & & \\
\hline (7) Takara & 58 & 26 & 32 & 46 & 0.69 & 12.7 & $17\left(7^{\prime}\right.$ & $24.7\left(7^{\prime \prime}\right.$ & \\
\hline \multicolumn{10}{|c|}{ Tuffaceous Sandstone } \\
\hline (8) Kamenose(1) & 91 & 37 & 54 & 22 & 2.57 & 9.9 & & $11.9(8)^{\prime \prime}$ & \\
\hline (9) Kamenose(2) & 96 & 39 & 57 & 25 & 2.28 & 11.4 & & & \\
\hline (10) Kamenose(3) & & & & 20 & & & & 15.77 & \\
\hline (11) Kamenose (4) & & & & 22 & & & & $14.4 \quad(d)$ & \\
\hline (12) Kamenose (5) & & & & 16 & & & & 13. 0$]$ & \\
\hline \multirow{2}{*}{$\begin{array}{l}\text { (13) Bentonite } \\
\text { Kaolin }\end{array}$} & 239 & 33 & 206 & 70 & 2. 96 & 6.8 & & & \\
\hline & 76 & 32 & 44 & 98 & 0.45 & & & . & \\
\hline \multicolumn{10}{|l|}{ Blue London Clay } \\
\hline (14) Wraysbury (1) & 72 & 29 & 43 & 57 & 0.75 & 9.4 & & (Bishop & , 1971) \\
\hline (15) Wraysbury (2) & 72 & 22 & 50 & 60 & 0.83 & 9.3 & & (Gatta & , 1970) \\
\hline (16) Wraysbury (3) & 70 & 29 & 41 & 58 & 0.71 & & 13.5 & (Agarwal & , 1967) \\
\hline \multicolumn{10}{|l|}{ Brown London Clay } \\
\hline $\begin{array}{l}\text { (17) Walthamstow } \\
\text { Weald Clay }\end{array}$ & 66 & 24 & 42 & 53 & 0.79 & 10.0 & & (Garga & , 1970) \\
\hline $\begin{array}{l}\text { (18) Arlington } \\
\text { London Clay }\end{array}$ & 65 & 32 & 33 & 52 & 0.63 & 12.0 & & (Garga & , 1970) \\
\hline (19) Essex & 82 & 29 & 53 & 55 & 0.96 & & 16 & (Skempton & , 1964) \\
\hline (20) Selset & 26 & 13 & 13 & 17 & 0.76 & & 30 & (Skempton & , 1964) \\
\hline (21) Jari & 70 & 27 & 43 & 47 & 0.91 & & 18 & (Skempton & , 1964) \\
\hline
\end{tabular}

Note; (a) Drained ring shear tests on the undisturbed pre-cut plane (b) Reversal direct shear box tests on the undisturbed pre-cut plane (c) Drained ring shear tests on the slurry (d) Reversal direct shear box tests on the slurry 


\section{4. すべり面強度定数}

リング剪断試験によって求めた粘土質島尻層泥岩の残 留剪断抵抗伤は, Slickenside の発達程度, 破䂶粘土粒子 や介在水の影響によって $\phi_{d r}=10 \sim 20^{\circ}$ の螌困で変化す る。一方，いくつかの地すべり・崩壊事例についての解 析結果で $c^{\prime}-\phi^{\prime}$ は図に抽いて $\phi^{\prime}=15^{\circ}$ とした場合に $\bar{c}^{\prime}=$ $0 \sim 3 \mathrm{tf} / \mathrm{m}^{2}$ となり, ピーク強さ $\left(c_{f}{ }^{\prime}=5 \sim 30 \mathrm{tf} / \mathrm{m}^{2}\right.$, $\left.\phi_{f}{ }^{\prime}=40 \sim 45^{\circ}\right)$ と比較して藷しく小さい。そして残留係 数は $R=0.85 \sim 0.95$ となり,すべり面強さが残留強さ 近くまで低下していることがわかる9,10)。

中頸城および東頸城の黑色泥岩の地すべり斜面でも安 定解析結果が活動中の現実斜面と適合しないことが多い ため, 真のすべり強さとそれに対応する安全率を実際の 地すべり斜面から求めることを試みている。すなわち, 杭打工事によって移動が停止した状態を $F_{s}=1$ とし, 逆 算法によって得られる $c^{\prime}-\phi^{\prime}$ 図に扎いて $\phi^{\prime}=5 \sim 7^{\circ}$ (ヘ ントナイトの $\phi_{d r}$ 值に担当）のような值を仮定して $\bar{c}^{\prime}=$ $0 \sim 35 \mathrm{tf} / \mathrm{m}^{2}$ を求めている11。

旧来，他の瀬地すべりでは，安定計算に使用してきた 強度定数が逆算法によって求めたものであり, 变付けの ない不確実なものであったため, スラリー試料を用いた 繰返し直接剪断試駼結果の残留強度定数をわずかに修正 した值をすべり面強度定数 $\left(\bar{c}^{\prime}=0\right.$ と $\phi^{\prime}=9.9^{\circ}, \bar{c}^{\prime}=0$ と $\left.\phi^{\prime}=13.2^{\circ}\right)$ とし，比較的よい整合性を得たとしてい $ろ^{12)}$ 。しかし, 綝返し直接剪断試験よりもリング剪断試 験の方がより小さな残留値を与えること, スラリー試料 よりもSlickenside の発達した分離面の方がより小さな 残留值を与えること, 拉よび粘土化領域の存在等を葚案 した場合，龟の瀬地すべりでも残留強さを主としながら む完全軟化強さの部分的関与や $\bar{c}^{\prime}=0$ の概念をとり入れ るべきであろう。

实際，すべり面には Slickenside ばかりでなく,構造的 な破砕や滑動によって生成された完全軟化粘土の存在も 確認されていることから, 残留強さや完全軟化強さに基 づく定数決定法が採用されるべきであり，単に活動中と いらことで $\bar{c}^{\prime}=0$ としたり，層厚から直接 $\bar{c}^{\prime}$ を仮定する といった土質力学的变付けのない手法は妥当でないよう に思われる。

したがって，地すべり・崩塤の安定解析に適用できる すべり面強度定数とするためには，すべり面領域が完全 䖝化の状態か， Slickenside からなる線的状態か，ある いは両者の複合状態かを明確に把握し，適切な試料と適 正な剪断試験から得られる実験結果に地質・構造特性を 加味して強度定数を決定すれば，一㒸信頼性の高い評俩 が可能になる。

\section{5. 逆算法と実験定数を基本にした設計定数算} 定

地すべりには，すべり面がすでに形成されていること が一般の斜面安定問題と異なる点であり, 設計定数を決 めることはすべり面強度定数を求めることと同義であ る。定数の決定に際しては, 通常, 近算法を用いて $\bar{c}^{\prime}$ と

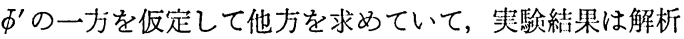
のための単なる参考资料となっている。しかし，より正 確な安定解析とするためにはサンプリング技術の向上や 剪断試験法の改善扣よび地すべり解析の経験等の成果を とり入れる必要があり，現在この種の研究が進められて いる。ここでは，逆算法と史駼定数を併用した手法につ いて解説する。

これは，すべり形態やすべり面の状態に注目し，実際 の $c^{\prime}-\phi^{\prime}$ 関係式と实験定数の組合せを基本に Mohr-Coulomb の式や残留係数を導入して平均寸べり面強度定数 の決定を行らものだが，すべりの形態によってその算定 方法が多少買なり，次の上うに分類される。

A-タイプ : Slickenside の形成されている線的な不連 続面を主すべり面とし，一部が岩実体部を切る，移 動量の小さい一次すべり

この場合, 分離面で働〈残留強さ $\tau_{d r}$ (定数 : $c_{d r}, \phi_{d r}$ ) と岩実体部のピーク強さ $\tau_{d f}\left(c_{d f}, \phi_{d f}\right)$ が滑動に対して同 時に抵抗しているので，すべり面強さ $\bar{\tau}\left(\bar{c}^{\prime}, \phi^{\prime}\right)$ は两者 の間に位置することになる。すなわち, Skempton の残 留係数

$$
R=\left(\tau_{d f}-\bar{\tau}\right) /\left(\tau_{d f}-\tau_{d r}\right)
$$

飞 Mohr-Coulomb の式

$$
\begin{aligned}
& \tau_{d r}=c_{d r}+\sigma_{n}{ }^{\prime} \tan \phi_{d r} \\
& \tau_{d f}=c_{d f}+\sigma_{n}{ }^{\prime} \tan \phi_{d f}
\end{aligned}
$$

を代入し，平均すべり面強さ

$$
\bar{\tau}=\bar{c}^{\prime}+\bar{\sigma}_{n}{ }^{\prime} \tan \phi^{\prime}
$$

と対応させれば，定数 $\bar{c}^{\prime} ， \phi^{\prime}$ の式が得られる。

$$
\begin{aligned}
& \bar{c}^{\prime}=R \cdot c_{d r}+(1-R) \cdot c_{d f} \cdots \cdots \cdots \cdots . . . \\
& \tan \phi^{\prime}=R \cdot \tan \phi_{d r}+(1-R) \cdot \tan \phi_{d f}
\end{aligned}
$$

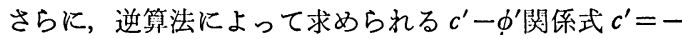
$a \cdot \tan \phi^{\prime}+b$ に招いて $a=\bar{\sigma}_{n}{ }^{\prime} ， \quad b=\bar{\tau}$ であることを考市れ ば，採取試料の残留招よびピーク強度定数と MohrCoulomb の式から $\bar{\sigma}_{n}{ }^{\prime}$ に対応する $\tau_{d r}$ および $\tau_{d f}$ が得ら れるので $R$ が決まり，定数 $\bar{c}^{\prime} ， \phi^{\prime}$ が算定できる。

B-タイプ：移動量の大きい地すべりの二次すべり

こののよらな地すべりでは，すべり面が全域にわたっ て形成されていて，通常， Slickensideの他に㨨乱した 完全軟化粘土薄層も存在する。したがって，静止の間に 強度が回復されるので, 残留強さと完全敕化強さ $\tau_{s d f}$ $\left(c_{s d f}, \phi_{s d f}\right)$ が関与することになる。 
この場合，残留係数が多少変形し，(7)式が成り立つ。

$$
\begin{aligned}
& R_{s}=\left(\tau_{s d f}-\bar{\tau}\right) /\left(\tau_{s d f}-\tau_{d r}\right) \\
& \tau_{s d f}=c_{s d f}+\sigma_{n}{ }^{\prime} \tan \phi_{s d f} \cdots . . .
\end{aligned}
$$

（7）式に（2)，(8) 式を代入すれば, 次式が得られる。 $\bar{c}^{\prime}=R_{s} \cdot c_{d r}+\left(1-R_{s}\right) c_{s d f}$

$\tan \phi^{\prime}=R_{s} \cdot \tan \phi_{d r}+(1-R) \tan \phi_{s d f}$

以下, $\mathrm{A}$ ータイプの場合と同様な手順にしたがえば，定 数 $\bar{c}^{\prime}, \Phi^{\prime}$ が算定できる。

C-タイプ：すべり面全体が高含水の地すべり粘土か らなる一次执よび二次すべり

この場合, 完全軟化強さ $\tau_{s d f}$ と $c^{\prime}-\phi^{\prime}$ 図を用いて定数 を算定する。すなわち， $\phi^{\prime}=\phi_{s d f}$ と打いて $c^{\prime}-\phi^{\prime}$ 関係式 から $\bar{c}^{\prime}$ を求める。

D-タイプ：移動量が大きくて活動中の地すべり

この場合, 分離面および完全軟化粘土のいずれも大変 位剪断状態にあるので, 当然残留強さが動員されている。 したがって， $\phi^{\prime}=\phi_{d r}$ とすれば $c^{\prime}-\phi^{\prime}$ 関係式から $\bar{c}^{\prime}$ が求 められる。

な拉，これらの方法には次のような特徵がある。

（イ）設計定数に土質力学的裏付けを与えるために，実 験定数を定数算定に組み入れた。

(口) 逆算法で得られる $c^{\prime}-\phi^{\prime}$ 関係を定数算定に組み入 れた。

(）如何なるタイプの地すべりに拈いても，基本的に 粘着力が存在するものとした。

（）すべり状況やすべり面の状態を定数算定に反映さ せた。

結局，A扣よび B-タイプの場合， $\bar{c}^{\prime}$ および $\phi^{\prime}$ は残留 強さとピークまたは完全軟化強さ，および $c^{\prime}-\phi^{\prime}$ 関係の 組合せによって計算できる。CおよびD-タイプの場合 は，それぞれ完全軟化強さや残留強さがすべり面に動員 されていることから，すべり面強さを摩擦成分主動のも のとしつつ,すべり面領域の複雑な様相や粘土の強度回 復現象および滑動にブレーキをかける諸々の不確定要素 が受け持つ抵抗の和を粘着力とした。すなわち，すべり 面強さのらち摩擦成分に対しては剪断特性を重視して, $\Phi^{\prime}=\phi_{s d f}$ または $\phi^{\prime}=\phi_{d r}$ とし， $c^{\prime}-\phi^{\prime}$ 関係から $\bar{c}^{\prime}$ を決定 した。

\section{6. 適用例}

\section{（1）真地団地内地すべり性崩壊10（那覇市）}

採取泥岩試料の剪断試験結果から，ピークおよび残留 強度定数は次のようになる。

ピーク : $c_{d f}=27.80 \mathrm{tf} / \mathrm{m}^{2}, \quad \phi_{d f}=43.2^{\circ}$

完全軟化 : $c_{s d f}=0.50 \mathrm{tf} / \mathrm{m}^{2}, \phi_{s d f}=26.7^{\circ}$

残 留: $c_{d r}=0, \quad \phi_{d r}=10.7^{\circ}$

主要すべり断面について簡便法によって安定計算を行 えば,（11)式が得られる。

$$
F_{s}=\frac{24.78 c^{\prime}+(184.43-75.45) \tan \phi^{\prime}}{112.46}
$$

i ）（11)式に特いて $F_{s}=1$ とすれば，(12)式になり, $c^{\prime}-\phi^{\prime}$ 図が描ける（図-2）。 $c^{\prime}=-4.398 \tan \phi^{\prime}+4.538$

ii ） ピーク，完全軟化打よび残留強度定数を適用し た場合の安全率の值 : 各定数を(11)式に代入して求 めた安全率を表-2に示す。ピーク強さを用いた場合 過大安全率が得られる反面, 完全軟化扣よび残留強 さを用いた場合は， $F_{s}<1$ となり，契際と矛盾する。

iii）平均すべり面強度定数 $\bar{c}^{\prime}, \phi^{\prime}$ : 当地すべりでは, 表土挔よび盛土の一部に顕著な移動がみられるが, 主すべりは，基岩にみられる小断層や強・弱風化岩 にみられる流れ盤状の節理扣よび層理面を弱面と し，一部すべり面形成まで至らない岩実体部を切る 小变位の初生すべりであるので，上記の A-タイプ を適用して，R=0.881, $\bar{c}^{\prime}=3.307 \mathrm{tf} / \mathrm{m}^{2}, \phi^{\prime}=15.6^{\circ}$ を得る。

\section{（2）識名園内地すべり性崩壊（那霸市）}

主要すべり断面を図-3に示す。採取泥岩試料のピークお よび残留強度定数は実験から次のようになる。

ピ 一.ク : $c_{d f}=4.10 \mathrm{tf} / \mathrm{m}^{2}, \phi_{d f}=38.1^{\circ}$

完全軟化 : $c_{s d f}=0.50 \mathrm{tf} / \mathrm{m}^{2}, \phi_{s d f}=26.7^{\circ}$

残 留: $c_{d r}=0, \phi_{d r}=10^{\circ}$

安定計算結果は，(13)式のようになる。

$$
F_{s}=\frac{23.85 c^{\prime}+(102.20-48.83) \tan \phi^{\prime}}{31.44}
$$

i ） $F_{s}=1$ としたとき $c^{\prime}$ の式は(14)式のようになり， $c^{\prime}$ - $\phi^{\prime}$ 図が描かれる(図-2)。

$c^{\prime}=-2.238 \tan \phi^{\prime}+1.318$.

ii ）ピーク，完全軟化および残留強度定数を適用し た場合の安全率の值 : 各定数を(13)式に代入して求 めた安全率は表-2に示すと拈りである。

iii）当地すべりでは，移動が顕著であること，ii）に 括ける結果のように完全軟化強さが平均すべり面強 さに近いこと，および強・弱風化層間の境界が明瞭 であるばかりでなく透水係数の差異によって形成さ

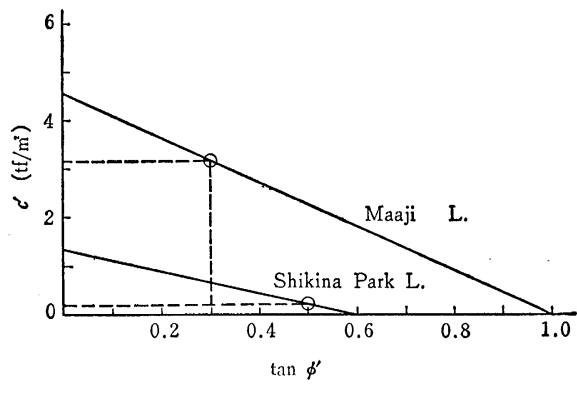

図-2 計算された $c^{\prime}-\phi^{\prime}$ 関係 


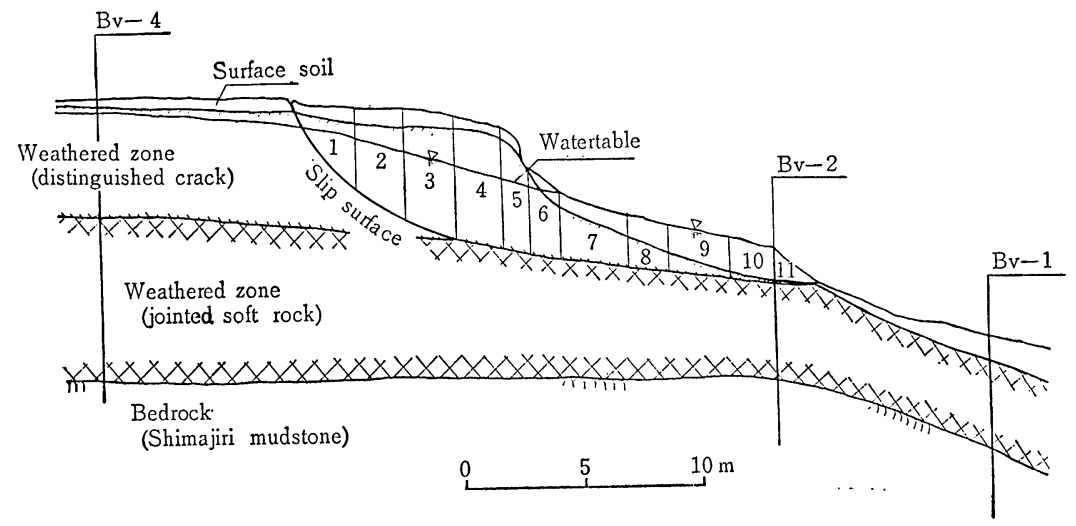

図-3 島尻層泥岩斜面における典型的な小規模のすべり状況断面図（那䐝市識名園内地す ベり性崩壊)

表-2 従来法と提案した方法による平均すべり面強度定数 $\bar{c}^{\prime}$ 扰よび $\phi^{\prime}$ の算定例

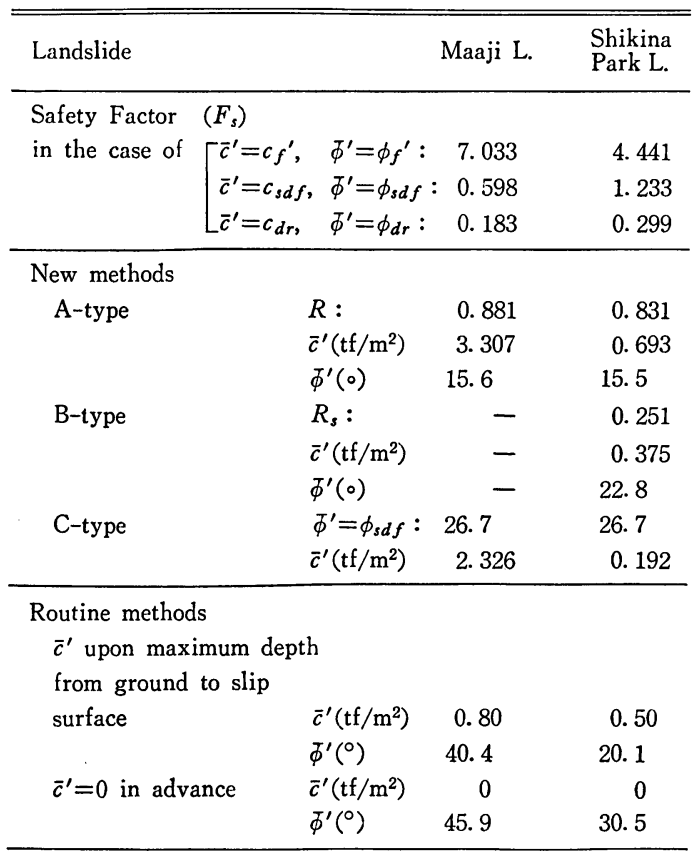

れる水みらがみられること等から，分離面が発揮す る残留強さと風化土や強風化岩㣣在粘土が発揮する 完全軟化強さの組合せを想定し，B-タイプを適用 した絬果, $R_{s}=0.251, \bar{c}^{\prime}=0.375 \mathrm{tf} / \mathrm{m}^{2}, \phi^{\prime}=22.8^{\circ}$ を 得た。

なお，参考までに，A-タイプを適用した場合の $\bar{c}^{\prime}$, $\phi^{\prime}$ も表-2に付記する。

（3）これらの事例に従来法を適用した結果を表一2に 示す。真地では $\phi^{\prime} か ゙$ 極端に大さくなっていて，些際に そぐわないことがわかる。

\section{7. あとがき}

地すべりの安定解析の精度を高めるためには，垁験結
果を単なる参考資料にとど めず，定数算定に組及入れ る必要がある。本論文で は，地すべり・崩壊のすべ り面領域に存在する Slickenside や完全軟化粘土に注 目し、すべり面強さと残留 強さ等の関係の重要性を指 摘した。そして，すべりの 形態，逆算法括よび剪断試 験で得られる強度定数の組 合せを基本に Mohr-Coulo$\mathrm{mb}$ の破壊規準や残留係数 を導入してょり合理的なす ベり面強度定数の算定を可 能にした。

最後に本論文をまとめるにあたり，ご協力いただいた 岐皋大学の仲野良紀教授, 琉球大学の城間理夫教授, 京 都大学の小橋澄治助教授之佐々恭二助教授, 近畿地建大 和工事事務所の方々，国土防災技術㑣の長野支店と新潟 支店の方々および利恨コンサルタント俶の尾崎雅鹳氏に 心から感謝申し上げます。

\section{参考文献}

1) 宜保清一：島尼層泥岩の残留強度测定と結果の解釈一地 ペリ・崩壊土への残留強度特性 ( I ) 一, 農桨土木学会論文 集, 104, pp. 61〜68(1983)

2）新潟県農林水産部治山課編：地すべり調查総括毒 III (1980)

3）望月巧一：断層沿いの地すべり—長野県北部，中山，小 谷, 持京断層上の例一, 地すべり, 13(4), pp. 11〜18(1977)

4）友松靖夫, 門脇 潡, 南澤正幸, 真砂祥之助: 龟の瀨地す べり（その 1）一龟の瀬地すべりの地質的背景一, 地す ベり, 18(2), pp. 1〜10(1981)

5) Nakano, R.: Geotechnical properties of mudstone of neogene tertiary in Japan, International Symposium on Soil Mechanics, Vol. 1, pp. 75 92(1679)

6）汇頭和彦, 宜保清一：沖縄, 島尻層群地带の地すべりに及 ぼす粘土の奇与, 地すべり, 19(4), pp. 1〜 7(1983)

7) Bishop, A, W., Green, G.E. and et al: A new ring shear apparatus and its application to the measurements of residual strength, Geotechnique, 21, pp. 273 328(1971)

8) Skempton, A.W.: Long term stability of clay slopes, Geotechnique, 14(2), pp. 77〜102(1964)

9）宜保清一：翁長地内地すべりの安定解析と排土工につい $\tau$, 琉球大学㕮学部学術報告, 27, pp. 247 255(1980)

10）宜保清一, 小波蔵政良, 吉沢光三 : 那羁市真地団地内地す ベり性崩壊の発生要因と平均せん断強度定数, 地すべり, 18 (2), pp. 11 18(1981)

11）福本安正, 富永功一, 佐藤 哲, 古川昭夫 : 破砕带地すへ りに护ける移動土塊と杭の挙動扣よび杭打効果について, 地 すべり, 19(3), pp. 1〜9(1983)

12）近畿地建大和工事事務所 : 龟の瀬地すべり対策事栄の計画 と調盗 (1981)

（原稿受理日 昭和58年10月26日） 
平均地すべり面強度定数の算定法について

「地すべり」Vol. 20，No.4，（通巻第76号）1984年（昭和59年） 3 月

宜保 清一, 武居 有恒, 小波蔵政良

地すべりの安定解析では, 剪断訊駼結果は単なる参考資料として取り扱われているが, 解析の精度を高めるた めには設計定数の算定に直接むたは間接的に実験定数を組み入れる必要がある。

本論文では，すべり面や節理面に形成されているSlickenside や完全軟化粘土薄層に注目し，すべり面強さと 残留強さ, ピーク強さおよび完全軟化強さとの関係の重要性を指摘しだ。そして残留強さ等の定数, Mohr-Coulomb の式および残留俰数 $R$ を逆算法によって得られる $c^{\prime}-\phi^{\prime}$ 関係汇導入して平均すべり面強度定数を決定する 方法を提案し，その合理性について子実際地すべり事例汇適用して確認した。

\section{すべり面のせん断強度定数と粘土鉱物との関係}

「地すべり」Vol. 20,No.4 (通巻第76号) 1984年（昭和59年）3月

\section{玉田 文吾}

地すべり粘土の内部摩擦角 $\phi^{\prime} は$, 土質試験時の試料の厚さ, ダイレイタンシーなどによって変化するが, 地 すべり粘土に含まれる粘土鉣物（モンモリロナイト）の含有率 $B_{n}$ にっってを変化し， $B_{n} \leqq 40 \%$ では

$$
\phi^{\prime}=\phi_{0} \exp \left(-A_{1} \cdot B_{n}\right)
$$

の関係がある。同時に，せ几断特性も $B_{n}$ の增加に伴なって排水形式から非排水形式へと変化する。 $\phi^{\prime}$ は，この ほが粘土鉱物以外の土粒子の鉱物組成㧊よび形状によっても多少変化するが, $B_{n}$ が $\phi^{\prime}$ 飞最も大きな影響を与 える。

今般の結果は，地すべり粘土の鉱物分析による $\phi^{\prime}$ の間接的な測定扰よび地すべり面探査に応用できる可能性 がある。

\section{阿武隈山地南部における山地崩壊に与える森林の影響}

「地すべり」Vol. 20, No. 4 (通巻第76号) 1984年（昭和59年） 3 月

\section{柴原 俊昭}

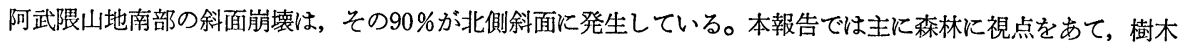
の成育状況を南北雨斜面で比較し, 崩壊発生との関係を調べた。その結果, 崩境は林令 12 年以下のところに多発 し, 同林令地でも北側斜面の樹木の成育の悪さが認められた。特に北側斜面での根系発達の悪さは土壊祭縛力を 弱內, 崩壊防止機能を低下させているものと考只られる。また，土壤層に执いても北側斜面の発達が悪く，母材 層との境が明膫であることから，土壌層と母材層の間がすべり面となって崩壊につながるものと考光られる。

\section{地温測定による地下水排除工の効果判定の可能性について}

一大石地すべり地を例として一

「地すべり」Vol. 20，No. 4 (通巻第76号）1984年（昭和59年） 3 月

竹内 篤雄, 二宮 寿男, 中村 和弘, 上野 郁夫

1980年 2 月に変成岩地带の地すべり地においてはじめて $1 \mathrm{~m}$ 深地温調查が实施され，それに基づいて地下水 排水工东が行われた。今回再度同一地区で地温調查が行われ，地温分布の再現性と施工された排水工事の効果が どのよらに地温分布に現われているかが検討された。その結果次のことが示された。

1）変成岩地带の地すべり地に扮いても $1 \mathrm{~m}$ 深地温分布の再現性は十分に認められる。

2）水脈内に掘られた調相用試錐孔の地下水位㧊よび横孔排水試錐からの排水量の勧測結果により排水工事の 効果の良好性が認められた。

3）排水効果の $1 \mathrm{~m}$ 深地温への影響は，排水工事施工前後の $\theta_{z-1}-y$ 図护よび地温分布図を対比することによ り明らかにされ，地温測定調査による排水効果判定の可能珄が示された。

4）地温分布図の対比によると, 排水工事の効果は工事区間ととの下流方向に大きく現われること, 排水工事 の施工密度の違いが地温分布状況に明らかに示されることがわかった。 